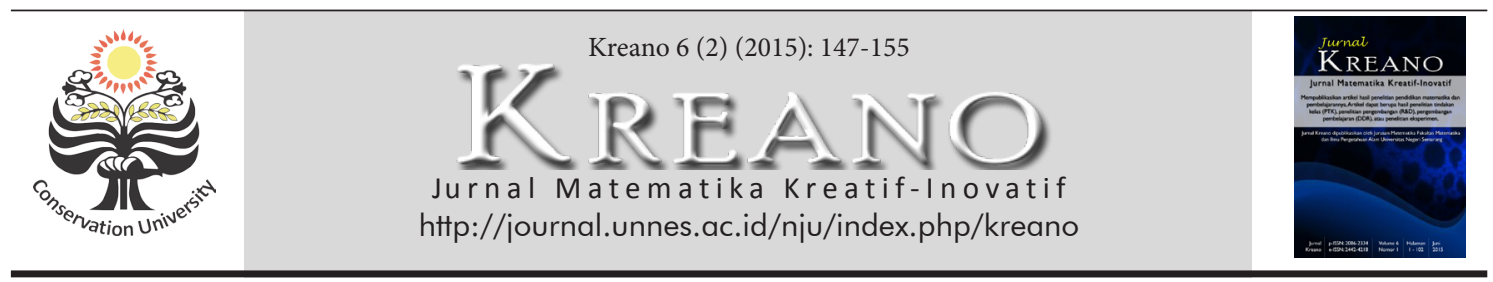

\title{
Stadion Gelora Sriwijaya Jakabaring dalam Pembelajaran Segitiga
}

\section{Nyiayu Fraisa Fatiyah; Ratu IIma Indra Putri2; dan Ely Susanti²}

\author{
'SMP Negeri 2 Indralaya Utara, Sumatera Selatan \\ 2Program Magister Pendidikan Matematika Universitas Sriwijaya \\ Email: nyiayufraisa@gmail.com
}

DOI: http://dx.doi.org/10.15294/kreano.v6i2.4830

Received : November 2015; Accepted: December 2015; Published: December 2015

\begin{abstract}
Abstrak
Penelitian ini bertujuan untuk menghasilkan lintasan belajar pada materi sifat-sifat segitiga berdasarkan panjang sisi dan besar sudutnya menggunakan konteks Stadion Gelora Sriwijaya Jakabaring di kelas VII. Desain pembelajaran yang digunakan terdiri dari tiga tahap yaitu preliminary design, design experiment (pilot experiment dan teaching experiment), dan retrospective analysis. Dalam penelitian ini, serangkaian aktifitas pembelajaran didesain dan dikembangkan berdasarkan pendekatan PMRI. Penelitian ini melibatkan 29 orang siswa kelas VII SMP Negeri 2 Indralaya Utara. Penelitian ini menghasilkan Learning Trajectory (LT) yang memuat serangkaian proses pembelajaran dalam 3 aktifitas yaitu menentukan jenis-jenis segitiga berdasarkan panjang sisi dan besar sudutnya, hubungan panjang sisi dan besar sudut pada segitiga dan menyelesaikan masalah yang berkaitan dengan sifat-sifat segitiga berdasarkan panjang sisi dan besar sudutnya. Hasil dari percobaan pembelajaran menunjukkan bahwa konteks Stadion Gelora Sriwijaya Jakabaring dapat digunakan sebagai starting point pada materi segitiga di kelas VII SMP.
\end{abstract}

\begin{abstract}
This research aims to produce a learning trajectory on the material properties of triangles based on the side and angle using the context Stadion Gelora Sriwijaya Jakabaring in class VII. Instructional design used consisted of three stages: preliminary design, design experiment (pilot experiment and teaching experiment), and retrospective analysis. This study used learning activities are designed and developed based on PMRI approach. Subjects were 29 seventh grade students of SMP Negeri 2 Indralaya Utara. This research resulted Learning Trajectory (LT), which contains a series of learning processes in the three activities that determine the types of triangles based on the side and angle, relationship side lenght and angle of the triangle and resolve problems related to the properties of triangles based on side length and angle. Results of the experiments showed that the Stadion Gelora Sriwijaya Jakabaring could be used as a starting point by seventh grade senior high school students to learn triangle.
\end{abstract}

Keywoords: Stadion Gelora Sriwijaya Jakabaring; PMRI; triangle.

\section{PENDAHULUAN}

Segitiga merupakan salah satu bentuk geometri yang sangat penting dan bermanfaat dalam kehidupan. Siswa tingkat SMP sangat perlu memahami materi sifat-sifat segitiga karena materi ini berkaitan dengan materi lain yang bahasannya lebih abstrak seperti teorema Phytaghoras, bangun ruang dan trigonometri. Selama ini, saat siswa dihadapkan pada sebuah gambar segitiga dan diminta untuk mengidentifikasi sifat-sifat dan menentukan jenis segitiga tersebut, siswa masih sering melakukan kekeliruan (Cutugno \& Spagnolo,
2006; Yezita, dkk, 2012). Untuk dapat mengkonstruksi sifat-sifat segitiga secara aktif dan bermakna akan membantu siswa mengembangkan level berpikir geometri mereka berdasarkan teori van Hiele (Fuys, et al, 1988) dari level 1 (visualisasi), level 2 (analisis) ke level 3 (deduksi informal) untuk siswa tingkat SMP usia 11-12 tahun ke atas (NCTM, 2002). Hal ini untuk menghindarkan siswa dari kegiatan menghafal sifat-sifat segitiga sebagai pernyataan lisan kosong tanpa kesempatan untuk mengalami pembelajaran yang bermakna (Rizkianto, 2012). 
Oleh karena itu, pembelajaran matematika pun harus bisa membuat siswa aktif untuk mengembangkan kemampuan-kemampuan dalam belajar sehingga dapat mencapai kompetensi yang telah ditetapkan. Salah satu upayanya adalah mengelola kegiatan pembelajaran matematika secara kontekstual atau realistik dengan pendekatan PMRI. PMRI dapat digunakan oleh para guru matematika dalam pengembangan kemampuan siswa untuk berfikir, bernalar, komunikasi, dan pemecahan masalah baik dalam pelajaran maupun dalam kehidupan sehari-hari (Zulkardi, 2002).

Wijaya (2012) merumuskan lima karakteristik PMRI yaitu:

\section{Penggunaan Konteks}

Konteks atau permasalahan realistik digunakan sebagai titik awal pembelajaran matematika. Konteks tidak harus berupa masalah dunia nyata namun bisa dalam bentuk permainan, penggunaan alat peraga atau situasi lain selama hal tersebut bermakna dan bisa dibayangkan dalam pikiran siswa. Dengan menggunakan konteks, selain siswa dapat dilibatkan secara aktif untuk melakukan eksplorasi permasalahan tetapi juga dapat menumbuhkan motivasi dan ketertarikan siswa dalam belajar matematikadan mengurangi kecemasan matematika atau mathematics anxiety. Dalam penelitian ini, peneliti menggunakan konteks Stadion Gelora Sriwijaya Jakabaring sebagai starting point pembelajaran sifat-sifat segitiga.

\section{Penggunaan model matematisasi progre-} sif

Model digunakan dalam melakukan matematisasi secara progresif. Model dalam matematika realistik merupakan jembatan penghubung dari situasi/konteks menuju ke tahap formal matematika melalui proses matematisasi. Dikenal model yang serupa atau mirip dengan masalah nyatanya yang disebut "model of" berupa bentuk-bentuk segitiga dan model yang mengarah ke pemikiran abstrak atau formal, yang disebut "model for" di mana siswa membuat sendiri bentuk-bentuk segitiga yang mereka temukan dari gambar formasi pemain sepakbola.
3. Pemanfaatan hasil konstruksi siswa Kontribusi yang besar pada proses belajar mengajar diharapkan dari konstruksi siswa sendiri yang mengarahkan mereka dari metode informal mereka ke arah yang lebih formal atau standar. Dari bentuk segitiga-segitiga yang telah dibuat oleh siswa, mereka dapat mengelompokkan segitiga-segitiga tersebut berdasarkan sifat-sifatnya dan menentukan hubungan panjang sisi dan sudut pada segitiga. Dalam hal ini siswa memiliki kebebasan untuk mengembangkan strategi mereka sendiri dalam pemecahan masalah sehingga diharapkan dapat diperoleh strategi yang bervariasi. Dari berbagai macam strategi yang digunakan siswa, siswa akan menyadari sendiri strategi mana yang paling efektif dalam memecahkan suatu masalah. Hal ini terlihat pada saat siswa menyelesaikan masalah yang berkaitan dengan sifat-sifat segitiga.

\section{Interaktivitas}

Dalam pembelajaran jelas perlu sekali melaksanakan interaksi baik antar siswa dan siswa maupun antara siswa dan guru yang berperan sebagai fasilitator. Interaksi mungkin terjadi antara siswa dengan sarana atau antara siswa dengan matematika maupun lingkungan. Bentuk interaksi dapat berupa negosiasi secara eksplisit, intervensi, diskusi, memberikan penjelasan, komunikasi, kooperatif dan evaluasi.

\section{Keterkaitan}

Konsep-konsep dalam matematika tidak bersifat parsial, namun banyak konsep matematika yang memiliki keterkaitan. PMRI menempatkan keterkaitan (intertwinement) antara konsep matematika sebagai hal penting yang harus dipertimbangkan dalam pembelajaran karena pada dasarnya konsep-konsep matematika tidak bersifat parsial, banyak konsep matematika yang memiliki keterkaitan. Pada pembelajaran materi segitiga ini berkaitan dengan pembelajaran olahraga yaitu menggunakan formasi pemain sepakbola dan ilmu pengetahuan umum yaitu konteks Stadion Gelora Sriwijaya Jakabaring sebagai starting point dalam pembelajaran.

Jerome Bruner, seorang ahli psikologi dari Universitas Harvard, Amerika Serikat te- 
lah mempelajari bagaimana manusia memperoleh pengetahuan, menyimpan pengetahuan dan mentransformasi pengetahuan (Depdiknas, 2004). Menurut Bruner, belajar merupakan suatu proses aktif yang memungkinkan manusia untuk menemukan hal-hal baru di luar informasi yang diberikan kepada dirinya. Sebagai contoh seorang siswa yang mempelajari sifat-sifat segitiga akan bisa menemukan hal penting dan menarik tentang sifat-sifat segitiga dan manfaatnya dalam kehidupan sehari-hari, sekalipun pada awal pembelajaran guru hanya memberikan sedikit informasi tentang sifat-sifat segitiga tersebut. Salah satu cara untuk membuat siswa menjadi aktif dalam pembelajaran adalah dengan memilih konteks yang tepat dan sesuai dengan materi yang dipelajari.

Konteks menjadi awal untuk pembelajaran matematika (Zulkardi dan Putri, 2006). Penggunaan konteks yang mengaitkan antara materi yang dipelajari dengan kehidupan nyata siswa sehari-hari akan lebih membiasakan siswa dalam pemecahan masalah. Zainab (2013) menyebutkan bahwa konteks di suatu daerah mungkin berbeda dengan di daerah lain sehingga menggunakan konteks nyata yang tepat lebih disarankan karena akan membantu siswa untuk mempersepsikan dan lebih mudah mengartikan informasi.

Pada penelitian ini, peneliti akan menggunakan konteks yang sesuai dengan materi segitiga yang tak jauh dari pikiran dan lingkungan siswa yaitu Stadion Gelora Sriwijaya Jakabaring sebagai starting point dalam pembelajaran sifat-sifat segitiga. Di dalam stadion ini terdapat bentuk-bentuk segitiga. Selain itu, stadion ini terkenal sebagai tempat pertandingan sepakbola level nasional maupun internasional sehingga peneliti juga menggunakan konteks formasi pemain sepakbola sebagai titik awal pembelajaran matematika dengan pendekatan PMRI pada materi sifat-sifat segitiga.

Berdasarkan pendahuluan tersebut, peneliti akan mendesain dan mengembangkan Local Instructional Theory (LIT) berupa Stadion Gelora Sriwijaya Jakabaring sebagai konteks lokal yang menjadi starting point dalam pembelajaran sifat-sifat segitiga. Adapun rumusan masalah dari pendahuluan tersebut adalah : "Bagaimana menghasilkan lintasan belajar yang dapat membantu siswa dalam memahami materi sifat-sifat segitiga berdasarkan panjang sisi dan besar sudutnya dengan pendekatan PMRI di kelas VII?" dan membahas peran konteks Stadion Gelora Sriwijaya Jakabaring dapat mendukung proses pembelajaran sifat-sifat segitiga serta strategi siswa dalam melakukan aktifitas pembelajaran yang telah dirancang peneliti.

\section{METODE}

Metode penelitian yang digunakan adalah metode design research yang melalui tiga tahap yaitu preliminary design, design experiment (pilot experiment dan teaching experiment), dan retrospective analysis. Dasar dari penelitian ini adalah proses siklus yang didesain berupa dugaan pembelajaran, tes dan merevisi dugaan pembelajaran tersebut di kelas sehingga menghasilkan lintasan belajar. Dugaan tersebut dianalisis lalu didesain kembali dan direvisi kemudian diimplementasikan lagi (Gravemeijer dan Cobb, 2001) yang terlihat pada Gambar 1.

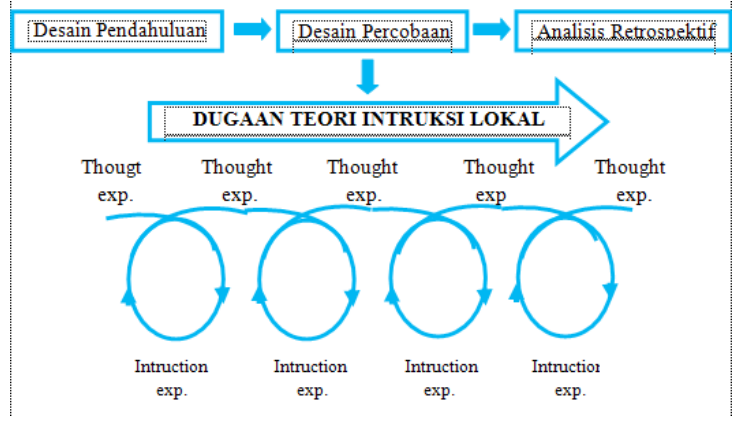

Gambar 1. Fase Penelitian Desain

Adapun subjek dari penelitian ini untuk tahap pilot experiment adalah 6 siswa kelas VII yang terbagi menjadi 3 kemampuan, yaitu tinggi, sedang dan rendah, dan tahap teaching experiment di kelas VII. 2 SMP Negeri 2 Indralaya Utara sebanyak 23 siswa. Tahapan penelitian ini, yaitu :

\section{Preliminary Design}

Pada tahap ini dilakukan kajian literatur mengenai materi pembelajaran yaitu sifat-sifat segitiga, PMRI dan mengembangkan konteks yang menggunakan Stadion Gelora Sriwijaya 
Jakabaring kemudian dikembangkan dengan formasi pemain sepakbola. Kemudian peneliti mendesain Hypothetical Learning Trajectory (HLT) akan dikembangkan serangkaian aktifitas pembelajaran yang memuat dugaandugaan yang terdiri dari tujuan pembelajaran, aktifitas pembelajaran dan perangkat yang dapat membantu proses pembelajaran. Dugaan tersebut dijadikan pedoman untuk mengantisipasi strategi dan berpikir siswa yang muncul dan dapat berkembang pada aktifitas pembelajaran. Dugaan ini bersifat dinamis sehingga dapat disesuaikan dengan reaksi siswa dalam belajar dan direvisi selama teaching experiment.

\section{Design Experiment}

Pada tahap ini, uji coba desain dilakukan secara bertahap. Tahap pertama yaitu pilot experiment diujicobakan pada kelompok kecil dan peneliti sebagai guru sedangkan guru model mengobservasi proses pembelajaran yang berlangsung. Setelah itu, peneliti akan melakukan diskusi dengan guru model agar HLT yang telah didesain dapat mencapai sasaran sesuai dengan tujuan pembelajaran yaitu pada materi sifat-sifat segitiga. Hasil dari diskusi dengan guru digunakan sebagai bahan pertimbangan dalam memperbaiki HLT. Pada kelas teaching experiment dilakukan oleh guru model pada satu kelas yang menjadi subjek penelitian. Revisi HLT pada pilot experiment dilaksanakan pada tahap ini sehingga strategi dan berpikir siswa dapat terlihat dengan menggunakan konteks Stadion Gelora Sriwijaya. Siswa juga akan diwawancarai pada proses pembelajaran untuk mengetahui pemahaman, kemajuan, dan kesulitan siswa.

\section{Retrospective Analysis}

Retrospective analysis akan dilakukan setelah design experiment dilakukan. Semua hal yang terjadi dalam proses pembelajaran (dilihat dari rekaman video dan observasi) akan dianalisis berdasarkan tujuan dari desain yang dibuat. Hasil aktifitas serta strategi siswa dideskripsikan. Tujuan dari retrospective analysis secara umum adalah untuk mengembangkan Local Instructional Theory (LIT). Pada tahap ini, HLT dibandingkan dengan pembelajaran siswa yang sebenarnya, hasilnya digunakan untuk menjawab rumusan masalah.

\section{HASIL DAN PEMBAHASAN}

Proses pembelajaran yang berlangsung terdiri dari beberapa aktifitas. Sebelum dan sesudah aktifitas dilakukan tes awal dan tes akhir guna mengetahui kemampuan pemahaman siswa. Adapun aktifitas yang dilakukan adalah sebagai berikut:

\section{a. Aktifitas 1 :}

Jenis-jenis segitiga berdasarkan panjang sisi dan besar sudut

Tujuan Pembelajaran :

Siswa dapat menggambarkan bentuk segitiga dari formasi pemain sepakbola kemudian menentukan jenis-jenis segitiga tersebut berdasarkan panjang sisi dan besar sudutnya.

Aktifitas Siswa :

Siswa mengeksplorasi bentuk-bentuk segitiga yang ada di Stadion Gelora Sriwijaya Jakabaring. Kemudian siswa menggambar bentuk segitiga dari formasi pemain sepakbola dan menentukan jenis-jenis segitiga tersebut. Siswa secara berkelompok mempresentasikan hasil lembar aktifitas yang telah dikerjakan dan menarik kesimpulan secara bersama-sama.

\section{Hasil Aktifitas :}

Adapun hasil dari aktifitas yang dilakukan adalah siswa mampu menggambar berbagai bentuk segitiga dari formasi pemain sepakbola kemudian menentukan jenis segitiga tersebut berdasarkan panjang sisi atau besar sudutnya. Beberapa kelompok kurang tepat melakukannya karena terlalu lama melakukan aktifitas menggambar dan menggunting segitiga yang dibuat. Hasil dari aktifitas ini dapat dilihat di Gambar 2.

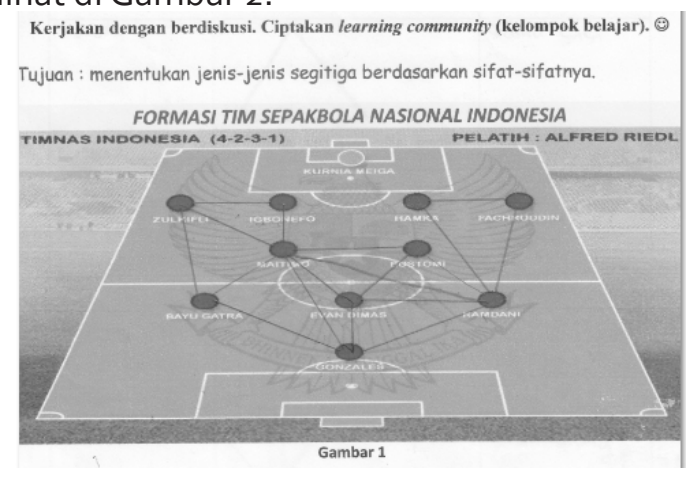

Gambar 2. Strategi Siswa dalam Membuat Segitiga 
Lembar aktifitas Kelompok 4 merupakan jawaban dari siswa yang menggambar semua bentuk segitiga yang mungkin sehingga menghasilkan lebih dari satu bentuk segitiga untuk satu jenis segitiga. Hal ini dapat dilihat pada hasil aktifitas di Gambar 3.

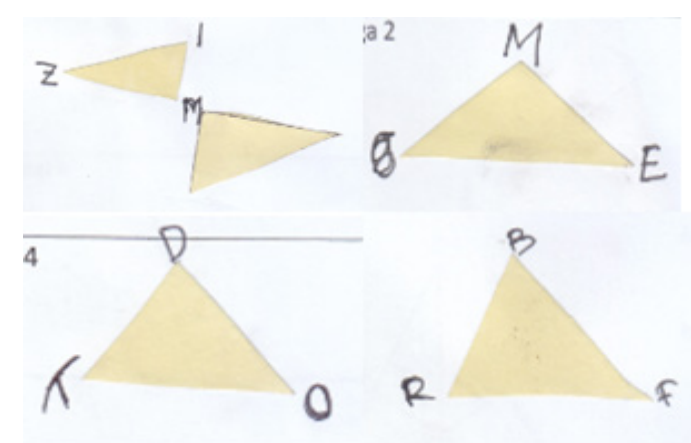

Gambar 3. Jenis-Jenis Segitiga Hasil Kelompok 4

Pada aktifitas selanjutnya, beberapa kelompok mampu menentukan jenis segitiga pada gambar dan menuliskan penjelasannya di lembar aktifitas. Setelah seluruh kelompok menyelesaikan lembar aktifitas, salah satu perwakilan kelompok mempresentasikan hasil aktifitas kelompoknya dalam diskusi kelas dan siswa yang lain memberikan tanggapan sehingga didapat kesimpulan dari aktifitas yang dilakukan.

\section{b. Aktifitas 2 :}

Hubungan panjang sisi dan besar sudut pada segitiga

Tujuan Pembelajaran :

Siswa dapat menunjukkan jumlah sudut dalam segitiga adalah $180^{\circ}$; menentukan sisi terpanjang, sisi terpendek, sudut terkecil dan sudut terbesar pada segitiga serta hubungan keduanya yang disebut ketidaksamaan segitiga; menentukan sudut luar dan hubungan besar sudut pada segitiga; dan menentukan hubungan panjang sisi dan besar sudut pada segitiga.

Aktifitas Siswa :

Dari segitiga yang telah dibuat pada aktifitas sebelumnya, siswa memilih salah satu jenis segitiga yang kemudian digunakan untuk menyelesaikan lembar aktifitas. Ada 4(empat) aktifitas yang akan dilakukan siswa. Siswa secara berkelompok mempresentasikan hasil lembar aktifitas yang telah dikerjakan dan menarik kesimpulan secara bersama-sama.

Hasil Aktifitas:

Adapun hasil aktifitas 1 yaitu menunjukkan jumlah sudut dalam segitiga adalah $180^{\circ}$, yang dilakukan siswa secara berkelompok dengan bentuk segitiga ada yang sama dan berbeda antar kelompok dapat dilihat pada Gambar 4.

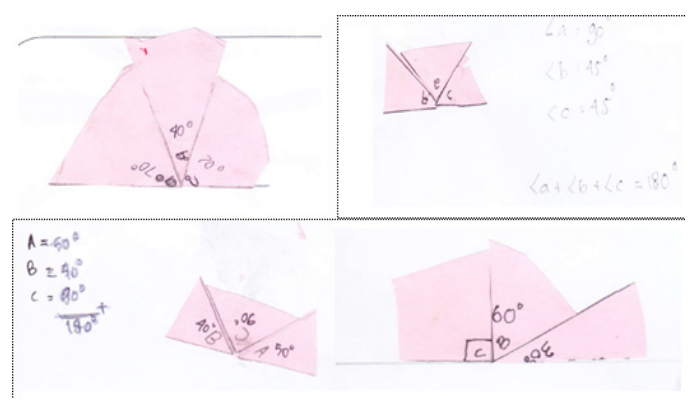

Gambar 4. Hasil Aktifitas 1

Dari empat jenis segitiga yang berbeda yang dibuat siswa mempunyai besar sudut yang berbeda-beda. Pada aktifitas ini, semua kelompok siswa mampu menyelesaikan dengan tepat.

Pada aktifitas 2 yaitu menentukan sisi terpanjang, sisi terpendek, sudut terkecil dan sudut terbesar pada segitiga dan hubungan keduanya dapat dilihat dari hasil aktifitas di Gambar $5 a$. dan 5 b.

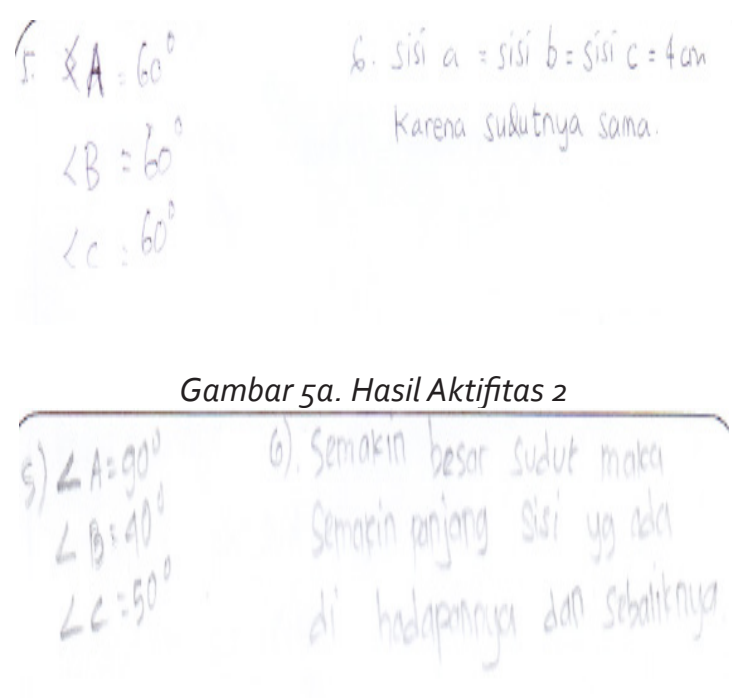

Gambar 5b. Hasil Aktifitas 2 
Dari kedua hasil aktifitas siswa mempunyai strategi yang berbeda. Pada Gambar $5 a$, siswa menggunakan jenis segitiga sama sisi sehingga mendapatkan bahwa pada segitiga sama sisi tidak ada sudut yang lebih besar dari sudut lainnya, begitu juga panjang sisi-sisinya, tidak ada sisi yang lebih panjang dari sisi lainnya. Sedangkan pada Gambar 5b, siswa menggunakan jenis segitiga siku-siku dengan sudut $90^{\circ}, 40^{\circ}$ dan $50^{\circ}$ sehingga didapat bahwa semakin besar sudut maka semakin panjang sisi yang ada di hadapan sudut itu. Dalam hal ini sudut $90^{\circ}$ adalah sudut yang terbesar sehingga sisi di hadapan sudut $90^{\circ}$ adalah sisi yang terpanjang, inilah yang disebut dengan ketidaksamaan segitiga.

Pada aktifitas 3, menentukan sudut luar dan hubungan besar sudut pada segitiga. Hasil aktifitas siswa pada segitiga yang sama menghasilkan jawaban yang berbeda berdasarkan strategi yang mereka gunakan masingmasing. Hal ini terlihat dari hasil lembar aktifitas pada Gambar 6 .

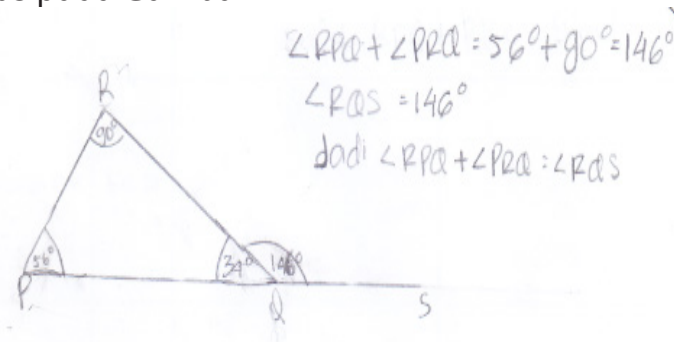

Gambar 6. Hasil Aktifitas 3

Hasil aktifitas siswa pada segitiga yang sama menghasilkan penyelesaian yang berbeda berdasarkan strategi masing-masing siswa. Ketelitian dalam mengukur besar masing-masing sudut segitiga mempengaruhi hasil yang diperoleh. Pada aktifitas ini, siswa terlebih dahulu mengukur besar sudut RPO dan sudut PRO kemudian menjumlahkannya sehingga mendapatkan hasil yang sama dengan besar sudut ROS. Dari aktifitas ini siswa dapat menentukan bahwa sudut luar segitiga adalah jumlah dari dua sudut dalam segitiga yang tidak berpelurus.

Aktifitas terakhir pada pembelajaran ini yaitu menentukan hubungan panjang sisi dan besar sudut pada segitiga. Adapun hasil aktifitas yang dilakukan siswa dilihat dari hasil lem- bar aktifitas berikut.

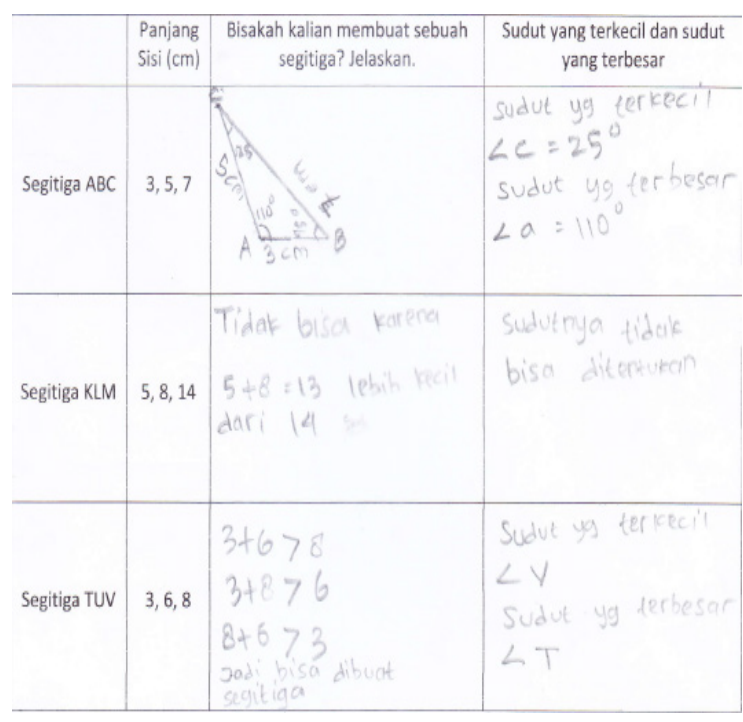

Gambar 7a. Hasil Aktifitas 4

Terlihat dari hasil lembar aktifitas, siswa mampu menentukan apakah panjang sisi yang telah ditentukan dapat dibuat segitiga. Dari aktifitas ini, pemahaman konsep siswa dapat terlihat dari siswa melengkapi strateginya dengan menggambar segitiga sebagai representasi jawabannya.

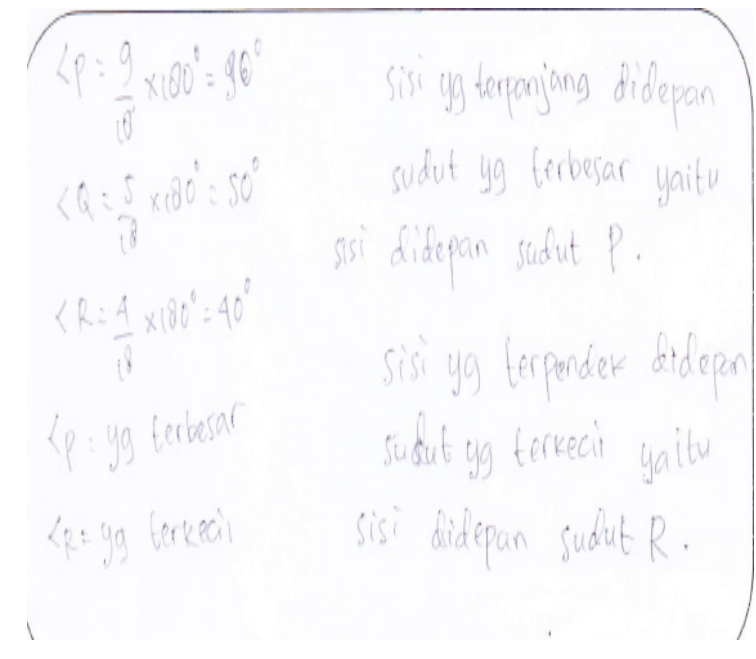

Gambar 7b. Hasil Aktifitas 4

Sedangkan hasil aktifitas pada Gambar $7 b$, terlihat bahwa siswa telah memahami dan mampu menentukan hubungan panjang sisi 
dan besar sudut pada segitiga.

\section{c. Aktifitas 3 :}

Menyelesaikan masalah yang berkaitan dengan sifat-sifat segitiga berdasarkan panjang sisi dan besar sudutnya.

Tujuan Pembelajaran :

Siswa dapat menyelesaikan masalah yang berkaitan dengan sifat-sifat segitiga berdasarkan panjang sisi dan besar sudutnya.

Aktifitas Siswa :

Siswa secara berkelompok menyelesaikan beberapa masalah yang merupakan aplikasi dari pemahaman sifat-sifat segitiga yang telah dipelajari sebelumnya.

Hasil Aktifitas :

Secara kelompok, siswa telah mampu menyelesaikan masalah yang berkaitan dengan sifat-sifat segitiga berdasarkan panjang sisi dan besar sudutnya.

Dari hasil design research yang telah dilakukan, diperoleh lintasan belajar sifatsifat segitiga menggunakan konteks Stadion Gelora Sriwijaya Jakabaring dengan pendekatan PMRI di kelas VII SMP. Selain itu diperoleh strategi-strategi pemikiran siswa dalam menyelesaikan materi sifat-sifat segitiga berdasarkan panjang sisi dan besar sudutnya. Strategi tersebut merupakan dampak dari penerapan HLT yang telah didesain dan diujicobakan pada pilot experiment kemudian direvisi sesuai dengan pembelajaran yang telah terjadi sehingga dapat diterapkan pada teaching experiment yang menghasilkan Learning Trajectory.

Pembelajaran yang dilaksanakan menggunakan konteks Stadion Gelora Sriwijaya Jakabaring sebagi starting point untuk mengawali dan mengeksplorasi pengetahuan siswa tentang segitiga. Kemudian formasi pemain sepakbola sebagai ikon olahraga yang sering diselenggarakan di stadion tersebut digunakan untuk membuat pola pikir siswa lebih luas dalam menjangkau materi sifat-sifat segitiga. Untuk mendukung konteks tersebut maka pendekatan PMRI berperan besar dalam proses pembelajaran yang berlangsung lebih aktif dan bermakna.

Berdasarkan implementasi pendekatan PMRI di dalam desain pembelajaran, aktifitas siswa sudah terlihat sesuai dengan karakteris- tik PMRI (Wijaya, 2012) yang muncul dalam proses pembelajaran ini yaitu :

1) Menggunakan masalah kontekstual yaitu matematika dipandang sebagai kegiatan sehari-hari manusia sehingga memecahkan masalah kehidupan yang dihadapi atau dialami siswa merupakan bagian yang sangat penting. Siswa mengamati dan menemukan bentuk-bentuk segitiga yang terdapat di Stadion Gelora Sriwijaya Jakabaring. Kemudian siswa mengeksplorasi pengetahuannya tentang jenis-jenis segitiga dari formasi pemain sepakbola seperti yang terlihat pada Gambar 2.

2) Menggunakan model matematisasi progresif yaitu model yang merupakan jembatan penghubung dari situasi/konteks menuju ke tahap formal matematika melalui proses matematisasi. Dikenal model yang serupa atau mirip dengan masalah nyatanya yang disebut "model of" berupa bentuk-bentuk segitiga yang ada di Stadion Gelora Sriwijaya Jakabaring yang mengarah ke pemikiran abstrak atau formal yang disebut "model for" di mana siswa membuat sendiri bentuk-bentuk segitiga yang mereka temukan dari formasi pemain sepakbola. Kegiatan ini terlihat pada gambar berikut.

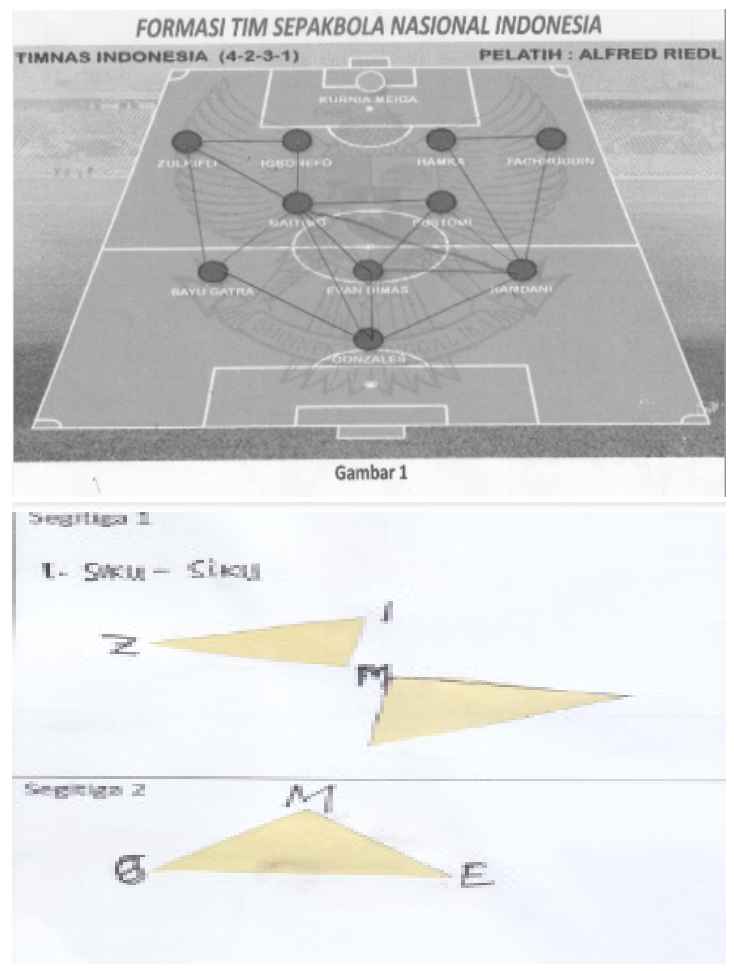

Gambar 8. Strategi Siswa Membuat Segitiga dari Formasi Pemain Sepakbola 
3) Pemanfaatan hasil konstruksi siswa Kontribusi yang besar pada proses belajar mengajar diharapkan dari konstruksi siswa sendiri yang mengarahkan mereka dari metode informal mereka ke arah yang lebih formal atau standar. Dari bentuk segitiga-segitiga yang telah dibuat oleh siswa, mereka dapat mengelompokkan segitiga-segitiga tersebut berdasarkan sifat-sifatnya, menentukan hubungan panjang sisi dan sudut pada segitiga dan menyelesaikan masalah yang berkaitan dengan sifat-sifat segitiga. Dalam hal ini siswa memiliki kebebasan untuk mengembangkan strategi mereka sendiri dalam pemecahan masalah sehingga diharapkan dapat diperoleh strategi yang bervariasi. Dari berbagai macam strategi yang digunakan siswa, siswa akan menyadari sendiri strategi mana yang paling efektif dalam memecahkan suatu masalah. Hal ini terlihat pada saat siswa menyelesaikan masalah yang berkaitan dengan sifat-sifat segitiga.

\section{4) Interaktivitas}

Dalam pembelajaran jelas perlu sekali melaksanakan interaksi baik antar siswa dan siswa maupun antara siswa dan guru yang berperan sebagai fasilitator. Interaksi antara siswa dan guru meliputi kegiatan memecahkan masalah kontekstual yang realistik, mengorganisasikan pengalaman matematis, dan mendiskusikan hasil-hasil pemecahan masalah tersebut. Pada penelitian ini, proses pembelajaran yang terjadi berpusat pada siswa sehingga terjadi interaksi sesama siswa. Hal ini dapat dilihat dari aktifitas diskusi dan presentasi yang mereka lakukan.

\section{5) Keterkaitan}

Konsep-konsep dalam matematika tidak bersifat parsial, namun banyak konsep matematika yang memiliki keterkaitan. PMRI menempatkan keterkaitan (intertwinement) antara konsep matematika sebagai hal penting yang harus dipertimbangkan dalam pembelajaran karena pada dasarnya konsep-konsep matematika tidak bersifat parsial, banyak konsep matematika yang memiliki keterkaitan. Pada pembelajaran materi segitiga ini berkaitan dengan pembelajaran olahraga yaitu menggunakan formasi pemain sepakbola dan ilmu pengetahuan umum yaitu Stadion Gelora Sriwijaya Jakabaring sebagai salah satu stadion berlevel internasional yang ada di Indonesia dan menjadi kebanggaan masyarakat Sumatera Selatan sebagai tuan rumah event olahraga Asian Games tahun 2018.

\section{PENUTUP}

Dari hasil penelitian yang didapat, penggunaan konteks Stadion Gelora Sriwijaya Jakabaring sebagai starting point memiliki peran dalam membantu siswa memahami sifat-sifat segitiga berdasarkan panjang sisi dan besar sudutnya. Untuk aktifitas pertama menentukan jenis-jenis segitiga berdasarkan panjang sisi dan besar sudutnya dari formasi pemain sepakbola, siswa menggunakan berbagai strategi untuk membuat berbagai jenis segitiga. Dari segitiga-segitiga yang telah dibuat oleh siswa, digunakan kembali pada aktifitas kedua yaitu menemukan hubungan panjang sisi dan besar sudut pada segitiga. Dari aktifitas kedua ini, muncul jawaban siswa yang berbeda dari masing-masing kelompok sehingga memperkaya pengetahuan yang diperoleh siswa. Pada aktifitas ketiga menyelesaikan masalah yang berkaitan dengan sifat-sifat segitiga, beberapa siswa belum dapat menyelesaikan masalah yang diberikan. Namun sebagian besar siswa telah dapat menyelesaikan masalah yang diberikan dengan beberapa strategi yang berbeda. Hal ini menunjukkan pemahaman siswa pada materi sifat-sifat segitiga dengan pendekatan PMRI menggunakan konteks Stadion Gelora Sriwijaya Jakabaring sudah cukup baik.

Serangkaian aktifitas yang didesain dan dikembangkan dengan pendekatan PMRI membantu siswa dalam mengembangkan strategi berpikirnya untuk mengemukakan ide atau gagasan dalam menyelesaikan aktifitas-aktifitas yang berkaitan dengan materi sifat-sifat segitiga berdasarkan panjang sisi dan besar sudutnya. Dari hasil penelitian ini juga didapat bahwa pemahaman yang tumbuh pada level situasional yaitu bentuk-bentuk segitiga yang ada pada Stadion Gelora Sriwijaya Jakabaring bergeser kepada pemahaman yang lebih formal dengan menentukan jenisjenis segitiga dari formasi pemain sepakbola. Pada tahap ini, segitiga yang telah dibuat oleh siswa pada aktifitas awal dapat digunakan un- 
tuk memahami hubungan antara panjang sisi dan besar sudut pada segitiga.

Lintasan belajar yang telah dilalui siswa meliputi 3 aktifitas yaitu :

a. Menentukan jenis-jenis segitiga berdasarkan panjang sisi dan besar sudut

Aktifitas pertama bertujuan agar siswa dapat menentukan jenis-jenis segitiga berdasarkan panjang sisi dan besar sudutnya. Pada aktifitas ini, siswa dapat menyelesaikan LAS dengan baik. Dari kegiatan-kegiatan pembelajaran yang dilakukan menyebabkan siswa dapat menentukan jenis-jenis segitiga berdasarkan panjang sisi dan besar sudutnya.

b. Hubungan besar sudut dan panjang sisi pada segitiga

Aktifitas kedua bertujuan agar siswa dapat memahami hubungan panjang sisi dan besar sudut pada segitiga yaitu :

1) Menunjukkan besar sudut dalam segitiga adalah $180^{\circ}$.

2) Menentukan sisi terpanjang, sisi terpendek, sudut terkecil dan sudut terbesar pada segitiga serta hubungan keduanya yang disebut ketidaksamaan segitiga.

3) Menentukan sudut luar pada segitiga.

4) Menentukan hubungan panjang sisi dan besar sudut pada segitiga.

Dari LAS yang diselesaikan siswa menunjukkan siswa dapat memahami hubungan panjang sisi dan besar sudut pada segitiga.

c. Menyelesaikan masalah yang berkaitan dengan sifat-sifat segitiga.

Dari masalah-masalah yang diberikan pada aktifitas ini menunjukkan siswa dapat menyelesaikan masalah yang berkaitan dengan sifat-sifat segitiga berdasarkan panjang sisi dan besar sudutnya.

\section{DAFTAR PUSTAKA}

Cutugno, P. \& Spagnolo, F. 2004. Misconceptions About Triangle in Elementary School. Diakses tanggal 24 Oktober 2014, pada http://math.unipa. it/ grim/SiCutugnoSpa.PDF

Depdiknas. 2004. Materi Pelatihan Terintegrasi Mata Pelajaran Matematika. Jakarta : Departemen Pendidikan Nasional

Fuys, David, Dorothy Geddes \& Rosamond Tischler. 1988. The van Hiele Model of Thinking in Geometry among Adolescents, Journal for Research in Mathematics Education. Monograph Series, no. 3 Reston, $\mathrm{Va}$ : National Council of Teacher of Mathematics

Gravemeijer, K. dan Cobb, P. 2001. Design Research From A Learning Design Perspective. Dalam Akker, dkk. (Ed.): Educational Design Research. New York: Routledge. HIm. 17-51.

National Council of Teachers of Mathematics (NCTM). 2000. Principles and Standards for School Mathematics. Reston, Va. : NCTM

Rizkianto, I. 2012. Design Research On Mathematics Education Constructing Geometric Properties of Rectangle, Square and Triangle in The Third Grade of Indonesian Primary School. Tesis PPs UNSRI.

Wijaya, A. 2012. Pendidikan Matematika Realistik : Suatu Alternatif Pendekatan Pembelajaran Matematika. Yogyakarta: Graha Ilmu.

Yezita, E. (2012). Mengkonstruksi Pengetahuan Siswa pada Materi Segitiga dan Segiempat Menggunakan Bahan Ajar Interaktif Matematika Berbasis Konstruktivisme. Jurnal Pendidikan Matematika, 1(1).

Zainab, Zulkardi, \& Yusuf, H. 2013. Desain Pembelajaran Materi Pola Bilangan Dengan Pendekatan PMRI Menggunakan Kerajinan Tradisional Kain Tajung Palembang Untuk Kelas IX SMP. Tesis PPs UNSRI.

Zulkardi. 2002. Developing A Learning Environment on Realistik Mathematics Education for Indonesian Student Teachers. Doctoral thesis of Twente University. Enschede: Twente University.

Zulkardi \& Putri, R. I. 2006. Mendesain Sendiri Soal Kontekstual Matematika, artikel dalam Paper terseleksi dan dipublikasikan pada Prosiding KNM 13, Semarang, 2006.

Zulkardi. 2009. The "P" in PMRI: Progress and Problems. In Proceedings of IICMA 2009 Mathematics Education, pp. 773-780. Yogyakarta: IndoMs. 